\title{
Pelaksanaan Pelatihan Dasar Calon Pegawai Negeri Sipil Golongan I/II Provinsi Gorontalo Tahun 2018
}

\author{
Thamrin A. Kum \\ Widyaiswara Badan Diklat Provinsi Gorontalo \\ Email : kumthamrin@yahoo.com
}

Received: 31 Oktober 2019; Revised: 17 Februari 2020; Accepted: 18 Februari 2020

\begin{abstract}
This research article aims to measure the participants' responses to the implementation of the basic training they attended. The research approach used is quantitative with the type of research used is descriptive survey. The results showed that the participants had a good perception of the implementation of the training related to the components of the training material, the organization of the training, facilities and lecturers / teaching staff that were shown with a very satisfying and satisfying percentage of more than 50\%, and there were only less than 50\% of the satisfactory scores. and unsatisfactory.
\end{abstract}

Keywords : Perception; Training; Employee

\begin{abstract}
Abstrak
Artikel Penelitian ini bertujuan untuk mengukur tanggapan peserta terhadap pelaksanaan pelatihan dasar yang mereka ikuti. Pendekatan penelitian yang digunakan ialah kuantitatif dengan jenis penelitian yang digunakan adalah Survey dekriptif. Hasil penelitian menunjukan bahwa peserta memiliki persepsi baik terhadap pelaksanaan pelatihan berkaitan dengan komponen materi pelatihan, penyelenggaraan pelatihan, sarana dan widyaiswara/tenaga pengajar yang ditunjukan dengan presentase nilai sangat memuaskan dan memuaskan lebih dari 50\%, dan hanya terdapat kurang dari $50 \%$ nilai cukup memuaskan dan kurang memuaskan.
\end{abstract}

Kata Kunci : Persepsi; Pelatihan; Pegawai

Link DOI : http://dx.doi.org/10.31314/pjia.8.2.101-109.2019 


\section{PENDAHULUAN}

Sebagai suatu bangsa Indonesia memiliki semua prakondisi untuk mewujudkan visi negara sebagaimana tertuang dalam Pembukaan UndangUndang Dasar Negara Republik Indonesia Tahun 1945, yang ditandai dengan kekayaan alam yang melimpah, potensi sumber daya manusia, peluang pasar yang besar dan demokrasi yang relatif stabil. Namun prakondisi yang sudah terpenuhi itu belum mampu dikelola secara efektif dan efisien oleh para aktor pembangunan, sehingga Indonesia masih tertinggal dari cepatnya laju pembangunan global dewasa ini.

Sumber daya manusia memainkan peranan yang penting dan strategis dalam mewujudkan tujuan pembangunan nasional. Kelemahan pada sumber daya manusia akan mempengaruhi upaya mewujudkan tujuan pembangunan nasional terancam tidak berhasil. Untuk menghindari kondisi yang tidak diinginkan ini maka mutlak diperlukan memanage sumber daya manusia aparatur pemerintah (Pegawai Negri Sipil) secara efektif, (Kum,T.A,2018)

\section{Pegawai Negeri Sipil (PNS)}

memiliki peranan yang menentukan dalam mengelola prakondisi tersebut. Sejumlah keputusan strategis mulai dari merumuskan kebijakan sampai pada implementasi kebijakan dalam berbagai sektor pembangunan dilaksanakan oleh PNS. Untuk memainkan peranan tersebut, diperlukan sosok PNS yang profesional, yaitu PNS yang mampu memenuhi standar kompetensi jabatannya sehingga mampu melaksanakan tugas jabatannya secara efektif dan efisien. Untuk dapat membentuk sosok PNS profesional seperti tersebut di atas perlu dilaksanakan pembinaan melalui jalur pelatihan. Selama ini pelatihan pembentukan Calon Pegawai Negeri Sipil (CPNS) dilakukan melalui Pendidikan dan Pelatihan Prajabatan (Diklat Prajabatan), dimana praktik penyelenggaraan Pelatihan yang pembelajarannya didominasi oleh ceramah sulit membentuk karakter PNS yang kuat dan profesional. Sejalan dengan telah ditetapkannya Undang-Undang Nomor 5 Tahun 2014 tentang Aparatur Sipil Negara (UU ASN) dan merujuk Pasal 63 ayat (3) dan ayat (4); CPNS wajib menjalani masa percobaan yang dilaksanakan melalui proses Diklat terintegrasi untuk membangun integritas moral, kejujuran, semangat dan motivasi nasionalisme dan kebangsaan, karakter kepribadian yang unggul dan bertanggungjawab, dan memperkuat profesionalisme serta kompetensi bidang. Diperlukan sebuah penyelenggaraan Pelatihan yang inovatif dan terintegrasi, yaitu penyelenggaraan Pelatihan yang memadukan pembelajaran klasikal dan non-klasikal di tempat Pelatihan dan di tempat kerja sehingga memungkinkan peserta mampu menginternalisasi, menerapkan, dan mengaktulisasikan, serta membuatnya menjadi kebiasaan (habituasi). Pelatihan ini disebut Pelatihan Dasar Calon Pegawai Negeri Sipil.

\begin{tabular}{cccc}
\multicolumn{2}{c}{ Pelatihan } & Dasar Calon PNS \\
Golongan I & dan Golongan & II
\end{tabular} diselenggarakan untuk membentuk PNS profesional yang berkarakter yaitu PNS yang karakternya dibentuk oleh sikap dan perilaku displin PNS, nilai- nilai dasar PNS, dan pengetahuan tentang kedudukan dan peran PNS dalam NKRI, serta menguasai bidang tugasnya sehingga mampu melaksanakan tugas dan perannya secara profesional sebagai pelayan masyarakat. Jika tujuan Pelatihan Dasar ini tercapai maka pelaksanaannya dikatakan efektif. Hal ini sebagaimana dikatakan 
Nana Sudjana(1990;50) efektifitas dapat diartikan sebagai tindakan keberhasilan peserta didik untuk tujuan tertentu yang dapat membawa hasil belajar secara maksimal.

Dalam upaya mengetahui apakah pelatihan dasar bagi CPNS ini efektif untuk membentuk PNS profesional yang berkarakter sebagaimana diuraikan di atas maka perlu dilakukan penelitian secara ilmiah dengan cara menganalisis persepsi dari para peserta yang mengikuti pelatihan. Menurut Kamus Besar bahasa Indonesia, persepsi adalah tanggapan (penerimaan) langsung dari sesuatu; proses seseorang mengetahui beberapa hal melalui panca inderanya. Persepsi merupakan salah satu aspek psikologis yang penting bagi manusia dalam merespon kehadiran berbagai aspek dan gejala di sekitarnya. Persepsi mengandung pengertian yang sangat luas, menyangkut intern dan ekstern. Walgito (2003;70) menyatakan bahwa persepsi merupakan suatu proses pengorganisasian, penginterpretasian terhadap stimulus yang diterima oleh organisme atau individu sehingga menjadi sesuatu yang berarti dan merupakan aktivitas yang integrated dalam diri individu.

Respon dari persepsi dapat diekspresikan oleh setiap individu dengan berbagai macam bentuk. Stimulus mana yang akan mendapatkan respon dari individu tergantung pada perhatian individu yang bersangkutan. Berdasarkan hal tersebut, perasaan, kemampuan berpikir, pengalaman-pengalaman yang dimiliki individu tidak sama, maka dalam mempersepsi sesuatu stimulus, hasil persepsi mungkin akan berbeda antara individu satu dengan individu lain.

Setiap individu memiliki kecenderungan dalam melihat obyek yang sama dari sudut pandang yang berbeda.
Perbedaan sudut pandang tersebut bisa dipengaruhi oleh banyak faktor, diantaranuya adalah pengetahuan, pengalaman dan cara pandangnya. Persepsi juga berkaitan dengan cara pandang seseorang terhadap suatu objek tertentu dengan cara yang berbeda-beda dengan menggunakan alat indera yang dimiliki, kemudian berusaha untuk menafsirkannya. Adapun komponen pelatihan yang dapat dipersepsi peserta menurut Rukmini H.S (2000) meliputi komponen materi pelatihan, penyelenggaraan, sarana dan widaiswara/tenga pengajar.

Persepsi peserta pelatihan dipandang tepat untuk mengukur efektifitas pelaksanaan pelatihan oleh karena yang memberikan persepsi ini adalah mereka yang mengalami proses pelatihan sehingga apa yang mereka lihat, dengar dan rasakan dapat mereka sampaikan melalui instrumen pengumpulan data yang disiapkan.

\section{METODE PENELITIAN}

Metode penelitian yang digunakan adalah metode survey deskriptif. Metode survey adalah salah satu metode yang digunakan dalam penelitian sosial. Dalam survey, informasi dikumpulkan dari responden menggunakan angket atau kuesioner yang didistribusikan secara langsung sebagai instrumen pengumpulan data yang pokok. Pemberian skor dalam penelitian ini menggunakan skala likert. Skala likert menurut Sugiyono (2008) adalah skala yang dapat dipergunakan untuk mengukur sikap, pendapat dan persepsi seseorang atau sekelompok tentang suatu gejala atau fenomena sosial. Pengambilan sampel dilakukan dengan menggunakan teknik purposiv sampling. Menurut Sugiono (2008) Teknik purposiv sampling adalah teknik untuk menentukan sampel penelitian dengan beberapa pertimbangan tertentu dengan tujuan agar 
data yang diperoleh nantinya bisa lebih refresentatif. Jumalah responden dalam penelitian ini berjumlah 40 orang Calon Pegawai Negeri Sipil yang mengikuti Pelatihan Dasar.

Teknik pengumpulan data dilakukan dengan penyebaran dan pengisian kuesioner. Analisis data yang digunakan adalah analisis kuantitatif menggunakan hasil dengan tabel statistik dengan tahapan pengolahan data meliputi penafsiran data, reduksi data, pemeriksaan keabsahan data, diakhiri dengan menarik kesimpulan.

Instrumen penelitian menggunakan angket yang disusun berdasarkan komponen yang diteliti yakni persepsi peserta terhadap pelaksanaan pelatihan dasar calon pegawai negeri sipil yang mereka ikuti meliputi komponen materi pelatihan, penyelenggaraan, sarana dan widyaiswara/tenaga pengajar sehingga dapat diketahui tingkat kepuasaan peserta pelatihan. Setiap komponen terdiri dari beberapa indikator yang disusun penulis mengadaptasi dari hasil kajian teori yang dilakukan penulis mencakup :

1. Materi, dengan indikator :

a. Sistematika penyajian materi

b. Kejelasan/kemudahan materi untuk dipahami;

c. Kontribusi materi dalam peningkatan pengetahuan;

d. Manfaat untuk pekerjaan;

e. Kesesuaian materi dengan tujuan pelatihan.

2. Penyelenggaraan, dengan indikator

a. Kesesuaian pemberian materi dengan jadwal yang telah ditetapkan;

b. Kesesuaian isi materi dengan waktu yang tersedia;

c. Ketepatan waktu dalam pelaksanaan pelatihan;

d. Kesediaan panitia dalam membantu proses pelatihan;
3. Sarana, dengan indikator :

a. Kualitas audio visual atau alat peraga;

b. Konsumsi;

c. Bahan pelatihan;

d. Ruangan (luas, meja/kursi, cahaya, sirkulasi udara);

e. Asrama (luas dan fasilitasnya)

4. Kemampuan widyaiswara, dengan indikator

a. Penguasaan materi;

b. Tehnik penyampaian;

c. Cara menjawab pertanyaan

d. Bahasa yang digunakan;

e. Gerakan tubuh (gesture) dan mimik muka;

f. Intonasi dan kecepatan berbicara

Untuk mengetahui ukuran baik dan kurang baik persepsi peserta terhadap pelaksanaan Pelatihan Calon Pegawai Negeri Sipil yang diikutinya, maka ditetapkan persepsi peserta dikatakan "baik" jika persepsi sangat memuaskan dan memuaskan nilainya lebih dari $50 \%$, dikatakan "kurang baik" jika persepsi cukup memuaskan dan kurang memuaskan kurang dari 50\%. Untuk mengetahui tingkat kepuasan peserta maka ditetapkan range interpretasi berdasarkan skala likert, dimana skor 4 untuk kategori sangat memuaskan, skor 3 untuk kategori memuaskan, skor 2 untuk kategori cukup memuaskan dan skor 1 untuk kategori kurang memuaskan.

\section{HASIL DAN PEMBAHASAN}

Kegiatan penelitian diawali dengan menyebarkan angket kepada 40 respon, Setelah responden mengisi angket dan menyerahkan kepada penulis, penulis melakukan tabulasi dan analisis data berdasarkan tahapan-tahapan yang sudah ditetapkan. 
Tabel 1 Hasil Tabulasi dan Analisis Data

\begin{tabular}{|c|c|c|c|c|c|c|c|}
\hline \multirow{4}{*}{ N0 } & \multirow{4}{*}{$\begin{array}{l}\text { KOMPONEN/ } \\
\text { INDIKATOR }\end{array}$} & \multicolumn{6}{|c|}{ NILAI } \\
\hline & & \multicolumn{3}{|c|}{ BAIK } & \multicolumn{3}{|c|}{ KURANG BAIK } \\
\hline & & Sangat & & & Cukup & Kurang & \\
\hline & & $\begin{array}{l}\text { Memua } \\
\text { skan } \\
(\%)\end{array}$ & $\begin{array}{l}\text { Memuas } \\
\text { kan } \\
(\%)\end{array}$ & $\begin{array}{l}\text { Jlh } \\
(\%)\end{array}$ & $\begin{array}{l}\text { Memuas } \\
\text { kan } \\
(\%)\end{array}$ & $\begin{array}{l}\text { Memua } \\
\text { skan } \\
(\%)\end{array}$ & $\begin{array}{l}\mathrm{Jlh} \\
(\%)\end{array}$ \\
\hline I. & MATERI PELATIHAN & & & & & & \\
\hline 1. & Sistematika penyajian materi & 42.5 & 57.5 & 100 & - & - & - \\
\hline 2. & $\begin{array}{l}\text { Kejelasan/kemudahan materi } \\
\text { untuk dipahami }\end{array}$ & 40.0 & 57.5 & 97.5 & 2.5 & - & 2.5 \\
\hline 3. & $\begin{array}{l}\text { Kontribusi materi dalam } \\
\text { peningkatan pengetahuan }\end{array}$ & 42.5 & 55.5 & 97.5 & 2.5 & - & 2.5 \\
\hline 4. & Manfaat untuk pekerjaan & 40.0 & 60.0 & 100 & - & - & \\
\hline 5. & $\begin{array}{l}\text { Kesesuaian materi dengan } \\
\text { tujuan pelatihan }\end{array}$ & 37.5 & 62.5 & 100 & - & - & \\
\hline II. & PENYELENGGARAAN & & & & & & \\
\hline 6. & $\begin{array}{l}\text { Kesesuaian pemberian materi } \\
\text { dengan jadwal yang telah } \\
\text { ditetapkan }\end{array}$ & 45.0 & 52.5 & 97.5 & 2.5 & - & 2.5 \\
\hline 7. & $\begin{array}{l}\text { Kesesuaian isi materi dengan } \\
\text { waktu yang tersedia }\end{array}$ & 47.5 & 50.0 & 97.5 & 2.5 & - & 2.5 \\
\hline 8. & $\begin{array}{l}\text { Ketepatan waktu dalam } \\
\text { pelaksanaan pelatihan }\end{array}$ & 37.5 & 60.0 & 97.5 & 2,5 & - & 2.5 \\
\hline 9. & $\begin{array}{l}\text { Kesediaan panitia dalam } \\
\text { membantu proses pelatihan }\end{array}$ & 50.0 & 50.0 & 100 & - & - & - \\
\hline III & SARANA PELATIHAN & & & & & & \\
\hline 10 & $\begin{array}{l}\text { Kualitas audio visual atau alat } \\
\text { peraga }\end{array}$ & 40.0 & 57.5 & 97.5 & 2.5 & - & 2.5 \\
\hline 11 & Konsumsi & 45.0 & 50.0 & 95 & 5.0 & - & 5.0 \\
\hline 12 & Bahan Pelatihan & 37.5 & 60.0 & 97.5 & 2.5 & - & 2.5 \\
\hline 13 & $\begin{array}{l}\text { Ruangan (luas, meja/kursi, } \\
\text { cahaya, sirkulasi udara) }\end{array}$ & 37.5 & 62.5 & 100 & - & - & - \\
\hline 14 & Asrama (luas dan fasilitasnya) & 40.0 & 57.5 & 97.5 & 2.5 & - & 2.5 \\
\hline IV & KEMAMPUAN & & & & & & \\
\hline & PENGAJAR/WIDYAISWARA & & & & & & \\
\hline 15 & Penguasaan materi & 42.5 & 57.5 & 100 & - & - & - \\
\hline 16 & Tehnik penyampaian & 47.5 & 52.5 & 100 & - & - & - \\
\hline 17 & Cara menjawab pertanyaan & 37.5 & 62.5 & 100 & - & - & - \\
\hline 18 & Bahasa yang digunakan & 42.5 & 57.5 & 100 & - & - & - \\
\hline 19 & $\begin{array}{l}\text { Gerakan tubuh (gesture) dan } \\
\text { mimik muka }\end{array}$ & 40.0 & 60.0 & 100 & - & - & - \\
\hline 20 & $\begin{array}{l}\text { Intonasi dan } \quad \text { kecepatan } \\
\text { berbicara }\end{array}$ & 40.0 & 60.0 & 100 & - & - & - \\
\hline
\end{tabular}

Sumber : Olahan Data Primer

Berdasarkan data pada tabel 1 dapat diketahui bahwa persepsi peserta terhadap komponen pelaksanaan Pelatihan Dasar CPNS tahun 2018 diuraikan sebagai berikut :

\section{Komponen Materi Pelatihan}

Persepsi peserta pelatihan terhadap komponen materi pelatihan dalam pelaksanaan pelatihan dasar CPNS provinsi Gorontalo adalah baik. 
Hal ini ditunjukan oleh prosentase sangat memuaskan dan memuaskan lebih dari 50\%. Dengan demikian pelaksanaan Pelatihan Dasar CPNS dilihat dari komponen materi pelatihan efektif. Materi pembelajaran adalah pengetahuan. keterampilan dan sikap yang harus dikuasai peserta pelatihan dalamn rangka memenuhi standar kompetensi yang ditetapkan. Kurniasih dan Sani, (2014) berpendapat secara garis besar dapat dikemukakan bahwa materi pembelajaran adalah pengetahuan, keterampilan dan sikap yang harus dikuasai oleh peserta didik dalam rangka memenuhi standar kompetensi yang ditetapkan. Prinsipprinsip yang dijadikan dasar dalam menentukan materi pembelajaran, yaitu 1) relevansi, kesesuaian materi dengan pencapaian standar kompetensi dan kompetensi dasar yang sudah ditetapkan., 2) Keajegan, kesesuian antara materi dengan jumlah kompetensi dasar yang harus dikuasai peserta didik, 3) Adquency, materi yang diajarkan memenuhi unsur kecukupan, dalam hal ini materi yang diajarkan hendaknya cukup memadai dalam membantu peserta didik menguasai kompetensi dasar yang diajarkan.

Dalam pengembangan materi belajar harus mampu mengidentifikasi dan mempertimbangkan hal-hal berikut : 1) potensi peserta didik, meliputi potensi intelektual, emosional, spiritual, sosial dan potensi vokasional, 2) relevansi dengan karakteristik daerah, 3) pengembangan materi pembelajaran diupayakan agar manfaatnya dapat dirasakan peserta didik dalam waktu yang relative singkat, 4) struktur keilmuan yang sesuai dengan materi pembelajaran suatu ilmu, 5) relevansi kebutuhan peserta didik dan tuntutan lingkungan, 6) memperhatikan alokasi waktu.

\section{Komponen Penyelenggaraan}

$$
\text { Persepsi peserta terhadap }
$$

komponen penyeleggaraan dalam pelaksanaan pelatihan dasar CPNS provinsi Gorontalo adalah baik. Hal ini ditunjukan oleh prosentase sangat memuaskan dan memuaskan lebih dari 50\% Dengan demikian pelaksanaan Pelatihan Dasar CPNS Provinsi Gorontalo dilihat dari komponen penyelenggaraan efektif.

Peraturan Kepala Lembaga Administrasi Negara Republik Indonesia nomor 22 tahun 2016 tentang Pedoman Penyelenggaraan Pelatihan Dasar CPNS menyebutkan bahwa ruang lingkup manajemen penyelenggaraan terdiri dari perencanaan, pelaksanaan, dan pengendalian dan pengawasan. Tahap pelaksanaan disebutkan meliputi antara lain lembaga pelaksana pelatihan dalam hal ini sebagai penyelenggara, waktu pelaksanaan pelatihan dan jadwal pelaksanaan pelatihan. Sebagai penyelenggara lembaga pelatihan haruslah memperhatikan 1) Kesesuaian pemberian materi dengan jadwal yang telah ditetapkan, 2) Kesesuaian isi materi dengan waktu yang tersedia, 3) Ketepatan waktu dalam pelaksanaan pelatihan, dan 4) Ketepatan waktu dalam pelaksanaan pelatihan.

106 Copyright (C) 2019, Publik (Jurnal Ilmu Administrasi), ISSN: 2301-573X (Print), ISSN: 2581-2084 (Online) 


\section{Aspek sarana Pelatihan}

Persepsi peserta terhadap

komponen sarana dalam pelaksanaan pelatihan dasar CPNS provinsi Gorontalo adalah baik. Hal ini ditunjukan oleh prosentase sangat memuaskan dan memuaskan lebih dari $50 \%$

Menurut Mulyasa, E (2008), Sarana Pendidikan adalah peralatan dan perlengkapan yang secara langsung dipergunakan dan menunjang proses pendidikan, khususnya proses belajar, mengajar, seperti bangunan, ruang kelas, meja kursi, serta alat-alat dan media pengajaran. Sarana pendidikan adalah semua keperluan yang diperlukan dalam proses belajarmengajar, baik yang bergerak maupun yang tidak bergerak agar pencapaian tujuan pendidikan dapat berjalan dengan lancar, teratur, efektif dan efisien. Dalam menyelenggarakan pembelajaran widyaiswara/tenaga pengajar memerlukan sarana yang dapat mendukung kinerjanya sehingga pembelajaran dapat berlangsung dengan menarik. Dengan dukungan sarana pembelajaran yang memadai, widyaiswara/tenaga pengajar tidak hanya menyampaikan materi secara lisan, tetapi juga dengan tulis dan peragaan sesuai dengan sarana prasarana yang telah disiapkan. Semakin lengkap dan memadai sarana pembelajaran yang dimiliki lembaga kediklatan akan memudahkan widyaiswara/tenaga pengajar dalam melaksanakan tugasnya sebagai tenaga pendidikan. Begitu pula dengan suasana selama kegiatan pembelajaran. Sarana pembelajaran harus dikembangkan agar dapat menunjang proses belajar mengajar.

Mengingat pentingnya sarana prasarana dalam kegiatan pembelajaran, maka peserta pelatihan, widyaiswara/tenaga pengajar dan lembaga kediklatan akan terkait secara langsung. Peserta pelatihan akan lebih terbantu dengan dukungan sarana prasarana pembelajaran. Tidak semua peserta didik mempunyai tingkat kecerdasan yang bagus sehingga penggunaan sarana prasarana pembelajaran akan membantu peserta didik, khususnya yang memiliki kelemahan dalam mengikuti kegiatan pembelajaran. Bagi widyaiswara/tenaga pengajar akan terbantu dengan dukungan fasilitas sarana prasarana. Kegiatan pembelajaran juga akan lebih variatif, menarik dan bermakna. Sedangkan lembaga kediklatan berkewajiban sebagai pihak yang paling bertanggung jawab terhadap pengelolaan seluruh kegiatan yang diselenggarakan. Selain menyediakan, lembaga kediklatan juga menjaga dan memelihara sarana prasarana yang telah dimiliki.

\section{KemampuanWidyaiswara/Tenaga Pengajar \\ Persepsi peserta terhadap komponen widyaiswara/tenaga} pengajar dalam pelaksanaan pelatihan dasar CPNS provinsi Gorontalo adalah baik. Hal ini ditunjukan oleh prosentase sangat memuaskan dan memuaskan lebih dari $50 \%$.

Copyright @ 2019, Publik (Jurnal Ilmu Administrasi), ISSN: 2301-573X (Print), ISSN: 2581- 
Widyaiswara sebagai salah satu unsur utama dalam pelaksanaan Pelatihan Dasar CPNS memiliki peran yang sangat strategis dan penting. Widyaiswara dapat dikatakan sebagai ujung tombak kualitas penyelenggaaraan suatu pelatihan,oleh karena peran widyaiswara terkait langsung dalam proses pembelajaran. Widyaiswara tidak hanya dituntut untuk menguasai substansi materi pelatihan tetapi juga harus menguasai teknik penyampaian atau transfer knowledge (Modul kebijakan pembinaan Widyaiswara dan angka kreditnya (LAN, 2016) sehingga hal ini menuntut widyaiswara/tenaga pengajar untuk memiliki kemampuan yang berkaitan dengan penguasaan materi, teknik penyampaian, cara menjawab pertanyaan, bahasa yang digunakan, gerakan tubuh dan mimik muka, serta intonasi dan kecepatan berbicara.

\section{PENUTUP}

\section{Kesimpulan}

Berdasarkan hasil penelitian yang telah dilakukan, dapat disimpulkan, bahwa pelaksanaan pelatihan dasar bagi CPNS Golongan I/II Provinsi Gorontalo tahun 2018 efektif, hal ini ditunjukan dengan 1) Persepsi peserta terhadap pelaksanaan pelatihan dasar CPNS yang diselenggarakan Badan Diklat Provinsi Gorontalo meliputi komponen materi, penyelenggaraan, sarana, dan aspek kemampuan Widyaiswara/Tenaga Pengajar adalah baik, 2) Dalam penelitan ini terlihat masih adanya peserta pelatihan yang menyatakan persepsinya terhadap pelaksanaan pelatihan dasar kurang baik khususnya pada aspek materi, penyelenggaraan, dan sarana, akan tetapi presentasinya rendah (dibawah $5 \%$ ).

\section{Saran}

Hendaknya dalam upaya menunjang terselenggaranya pelatihan pihak penyelenggara Diklat dapat lebih meningkatkan aspek peralatan dan sarana yang baik dan nyaman sehingga para peserta dapat mengikuti kegiatan pelatihan dengan baik.

\section{DAFTAR PUSTAKA}

Kum, T. A. (2018). Model Evaluasi Reaction Level dari Kickpatrick Penyelenggaraan Pendidikan dan Pelatihan Kepemimpinan Tingkat III Angkatan II Provinsi Gorontalo. Publik (Jurnal Ilmu Administrasi), 7(1), 63-69.

Kurniasih, Imas dan Berlin Sani. (2014). Perancangan Pembelajaran Prosedur Pembuatan RPP yang Sesuai Dengan Kurikulum 2013. Jakarta: Kata Pena.

LAN RI. (2016) Peraturan Kepala Lembaga Admiistrasi Negara nomor 22 tahun 2016 tentang pedoman penyelenggaraan pelatihan dasar calon pegawai negeri sipil Golongan I dan II

Mulyasa E, (2008), Kurikulum Tingkat Satuan Pendidikan, suatu panduan praktis Bandung : Rosda karya

108 Copyright (C) 2019, Publik (Jurnal Ilmu Administrasi), ISSN: 2301-573X (Print), ISSN: 2581-2084 (Online) 
Purwadarminta, W.J.S. (1976). Kamus

Umum Bahasa Indonesia.Jakarta :

Balai Pustaka

Sudjana, Nana. (1990). Penilaian Hasil

Proses Belajar Mengajar.

Bandung: PT Remaja Rosda Karya

Sugiyono. (2008). Metode penelitian kuantitatif, kualitatif dan $R \& D$. Bandung: Alfabeta.

Rukmini H.S, dkk (2000), Evaluasi Training dengan menggunakan model Kickpatrick. Jurnal Penelitian. Bandung Indonesia

Walgito, B. (2003). Psikologi umum. Yogyakarta: Andi Offsets.

Undang-Undang Nomor 5 tahun 2014 tentang Aparatur Sipil Negara

Peraturan Kepala Lembaga Administrasi Negara RI Nomor 22 Tahun 2016 Tentang PedomanPenyelenggaraan Calon PNS 